\title{
Effects of follicular fluid at fertilization in vitro on sperm penetration in pig oocytes
}

\author{
H. Funahashi and B. N. Day* \\ Department of Animal Science, University of Missouri-Columbia, Columbia, MO 65211, USA
}

\begin{abstract}
The effects of porcine follicular fluid (PFF) on sperm penetration of pig oocytes and on prevention of polyspermy were examined and characteristics of spermatozoa exposed to PFF were determined. The addition of PFF at the level of 1 and $10 \%$ to the prefertilization and fertilization media decreased penetration rates and the mean number of spermatozoa in penetrated eggs regardless of the origin of PFF. In the presence of BSA, supplementation of $0.1 \%$ PFF to prefertilization and fertilization media and 1\% PFF to prefertilization media did not decrease the penetration rates but did increase monospermic penetration to 54 and $68 \%$, respectively. When PFF was added to prefertilization media, the number of spermatozoa binding to the zona and the percentage of acrosome-intact spermatozoa decreased with increased PFF concentration (from $43.1 \pm 2.8$ and $73.1 \pm 4.9 \%$ to $7.2 \pm 1.3$ and $15.7 \pm 15.4 \%$, respectively). At the end of prefertilization incubation, sperm agglutination was observed and the degree depended on PFF concentration. Supplementation of fetal calf serum to prefertilization and fertilization media blocked the effects of PFF on sperm penetration and binding of spermatozoa to the zona. These results indicate that the prefertilization incubation of porcine spermatozoa in suitable concentrations of porcine follicular fluid will effectively reduce both the number of spermatozoa that attach to the surface of pig eggs and the incidence of polyspermy.
\end{abstract}

\section{Introduction}

Pig follicular oocytes are a potential source of female gametes for increased production using various artificial techniques. Many successful in vitro fertilization (IVF) techniques for sperm penetration into pig oocytes matured in vivo or in vitro (Iritani et al., 1978; Nagai et al., 1984, 1988, 1990; Cheng et al., 1986; Yoshida 1987; Naito et al., 1988; Hamano et al., 1989; Mattioli et al., 1988; Yoshida et al., 1990, 1992; Wang et al., 1991; Zheng and Sirard, 1992) and also in vitro culture system of one-cell pig eggs to the blastocyst stage (Beckmann et al,, 1990; Petters et al., 1990; Beckmann and Day 1991; Hagen et al., 1991; Misener et al., 1991; Petters and Reed, 1991; Reed et al., 1992) have been developed. However, multiple sperm entry in pig oocytes has been repeatedly observed following IVF (Nagai et al., 1984; Cheng et al., 1986; Mattioli et al., 1988; Nagai and Moor, 1990; Wang et al., 1991; Zheng and Sirard, 1992). This abnormality remains a major unsolved problem.

Polyspermy can be induced experimentally in pigs by delayed mating, direct tubal insemination or progesterone treatment (see e.g. Day and Polge, 1968; Hunter, 1972; also see reviews by Hunter, 1990, 1991). It is believed that in vivo polyspermy is due to unsuitable cortical reaction by aged oocytes or an abnormally high number of spermatozoa reaching the site of fertilization (Hunter, 1990). Recently, Nagai and Moor (1990) suggested that macromolecules secreted from

* Correspondence.

Received 24 September 1992. pig oviductal epithelial cells may reduce the incidence of polyspermy in pig oocytes fertilized in vitro by means of some interaction with fertilizing spermatozoa, whereas the uterus and oviducts of the oestrous female provide the most favourable conditions for prerequisite changes in spermatozoa to accomplish fertilization, such as capacitation (Hunter and Hall, 1974; Yanagimachi, 1981; Hunter, 1990). However, the mechanism by which oviduct secretory products prevent polyspermic penetration of spermatozoa in pig oocytes is not clear. It is known that follicular fluid will promote capacitation and acrosome reaction of spermatozoa in vitro more effectively than does oviductal fluid in many species (Barros and Austin, 1967; Gwatkin and Anderson, 1969; Iwamatsu and Chang, 1969; Yanagimachi, 1969; Lenz et al., 1982). In rodents, the presence of follicular fluid in the fertilization medium allows sperm penetration (Gwatkin and Anderson 1969; Iwamatsu and Chang, 1969; Yanagimachi, 1969). Although it has been suggested that the small volume of follicular fluid discharged with oocytes from follicles is present at the place of fertilization in pigs and that the fluid has a stimulatory effect on the acrosome reaction of spermatozoa in the ampulla (Hansen et al., 1991), it is not known whether the follicular fluid at the place of fertilization regulates sperm penetration. If the macromolecules secreted from oviductal epithelial cells reduce the incidence of multiple entry of spermatozoa into pig oocytes by controlling a series of changes of spermatozoa needed to accomplish penetration, follicular fluid as well as oviductal secretions may affect sperm penetration and the incidence of polyspermy in pig oocytes in vitro. 
The present study was designed to determine whether the presence of pig follicular fluid at the site of fertilization in vitro affects sperm penetration and the incidence of polyspermy in pig oocytes.

\section{Materials and Methods}

\section{Preparation of supplements}

The supplements used in this study were prepared as follows: fetal calf serum (FCS) was purchased as a commercial product in heat-inactivated form (GIBCO Laboratories, Life Technologies Inc., Grand Island, NY). Newborn piglet serum (NPS) was obtained from fresh blood which was obtained from piglets within a few hours after birth. Porcine follicular fluid derived from immature follicles (IM-PFF) was collected from superficial follicles, 3-6 mm in diameter, of prepubertal pig ovaries within $4-6 \mathrm{~h}$ after slaughter. Porcine follicular fluid derived from mature follicles (M-PFF) was surgically aspirated from ovaries of cyclic gilts before ovulation, at $40-46 \mathrm{~h}$ after the onset of oestrus. All supplements, except FCS, were filtered through 1.2 and $0.45 \mu \mathrm{m}$ syringe filters. Supplements were stored at $-20^{\circ} \mathrm{C}$ until use.

\section{Culture media}

The basic medium (mM199) for the manipulation of oocytes and spermatozoa was Medium 199 with Earle's salts (GIBCO) supplemented with $3.05 \mathrm{mmol}$ D-glucose $\mathrm{I}^{-1}, 2.92 \mathrm{mmol}$ calcium lactate $\mathrm{l}^{-1}, 0.91 \mathrm{mmol}$ sodium pyruvate $\mathrm{l}^{-1}, 75 \mu \mathrm{g}$ potassium penicillin $\mathrm{G} \mathrm{ml}^{-1}$ and $50 \mu \mathrm{g}$ streptomycin sulfate $\mathrm{ml}^{-1}$. The basic oocyte maturation medium (OMM199) was mM199 supplemented with 10 iu pregnant mares' serum gonadotrophin $\mathrm{ml}^{-1}$ (PMSG; Intervet America Inc., DE), 10 iu hCG ml ${ }^{-1}$ (LyphoMed Inc., Rosemont, IL), $1 \mu$ g oestradiol $\mathrm{ml}^{-1}$ (Sigma Chemical Co., St Louis, MO) and $10 \%(\mathrm{v} / \mathrm{v})$ IM-PFF. The culture medium (modified Whitten's medium) for pig oocytes after co-culture with spermatozoa was Whitten's medium (Whitten and Biggers, 1968) which was modified by a change in the concentration of BSA (Fraction V, Sigma) to $1.5 \%(\mathrm{w} / \mathrm{v})$ as reported by Beckmann and Day (1991).

\section{Preparation and culture of follicular oocytes}

Ovaries were collected from prepubertal gilts at a local abattoir. Transportation of ovaries to the laboratory was carried out at $25^{\circ} \mathrm{C}$ in Dulbecco's phosphate-buffered saline (GIBCO) supplemented with $5.54 \mathrm{mmol}$ D-glucose $1^{-1}, 0.33 \mathrm{mmol}$ sodium pyruvate $\mathrm{I}^{-1}, 75 \mu \mathrm{g}$ potassium penicillin $\mathrm{G} \mathrm{ml}^{-1}$ and $50 \mu \mathrm{g}$ streptomycin sulfate $\mathrm{ml}^{-1}$ (mDPBS). Oocyte-cumulus cell complexes (OCC) were aspirated from follicles $3-6 \mathrm{~mm}$ in diameter. OCC with uniform cytoplasm and a compact cumulus mass were collected in mDPBS with $2 \%(\mathrm{v} / \mathrm{v})$ NPS and then washed three times with OMM199. Ten OCC were transferred to a droplet of $100 \mu \mathrm{l}$ of OMM199 covered with warm paraffin oil in a culture dish, and then cultured for $40 \mathrm{~h}$ at $39^{\circ} \mathrm{C}$ in an atmosphere of $5 \% \mathrm{CO}_{2}$ in air.

\section{Preparation of spermatozoa}

Sperm-rich fractions $(15 \mathrm{ml})$ were collected from a boar by the gloved hand method. After adding antibiotics (100 $\mu \mathrm{g}$ penicillin $\mathrm{G}$ sodium $\mathrm{ml}^{-1}, 100 \mu \mathrm{g}$ streptomycin sulfate $\mathrm{ml}^{-1}$ and $0.25 \mu \mathrm{g}$ amphotericin $\mathrm{B} \mathrm{ml}^{-1}$; GIBCO) the semen samples were kept at $20^{\circ} \mathrm{C}$ for $16 \mathrm{~h}$. Thereafter, $5 \mathrm{ml}$ of semen was mixed with the same volume of $0.9 \% \mathrm{NaCl}$ supplemented with $10 \mathrm{mg}$ BSA (fraction V, Sigma) $\mathrm{ml}^{-1}$ (BSA-saline solution) and centrifuged at $200 \mathrm{~g}$ for $3 \mathrm{~min}$. The top $5 \mathrm{ml}$ of supernatant containing spermatozoa was washed three times with BSA-saline solution by centrifugation at $1200 \mathrm{~g}$ for $3 \mathrm{~min}$ to remove seminal plasma. After washing, the pellets containing spermatozoa were resuspended at $2 \times 10^{8}$ cells $\mathrm{ml}^{-1}$ in mM199 at $\mathrm{pH} 7.8$ The sperm suspension was incubated for $90 \mathrm{~min}$ at $39^{\circ} \mathrm{C}$ in an atmosphere of $5 \% \mathrm{CO}_{2}$ in air (prefertilization incubation).

\section{In vitro fertilization}

After $40 \mathrm{~h}$ of culture, ten oocytes were removed from maturation medium, washed three times and placed into $50 \mu \mathrm{l}$ mM199 at $\mathrm{pH} 7.4$ supplemented with $10 \mathrm{mmol}$ caffeine sodium benzoate $1^{-1}$ (Wang et al., 1991), which was covered with paraffin oil in a culture dish. The dish was placed in an incubator at $39^{\circ} \mathrm{C}$ in an atmosphere of $5 \% \mathrm{CO}_{2}$ in air until spermatozoa were added for insemination. Fifty microlitres of diluted preincubated spermatozoa was added to $50 \mu \mathrm{l}$ of medium containing oocytes so that a final sperm concentration of $1 \times 10^{6}$ cells ml $^{-1}$ was obtained. Oocytes were co-cultured with spermatozoa for $6 \mathrm{~h}$ at $39^{\circ} \mathrm{C}$ in an atmosphere of $5 \% \mathrm{CO}_{2}$ in air. The eggs were then transferred to $100 \mu \mathrm{l}$ of fresh modified Whitten's medium and cultured for a further $6 \mathrm{~h}$ at $39^{\circ} \mathrm{C}$ in an atmosphere of $5 \%$ $\mathrm{CO}_{2}$ in air.

\section{Assessment of sperm penetration}

At the end of the culture, eggs were removed from the droplet and rinsed with mDPBS. Eggs were mounted, fixed for $48 \mathrm{~h}$ or more in $25 \%(\mathrm{v} / \mathrm{v})$ acetic alcohol at room temperature, stained with $1 \%(\mathrm{w} / \mathrm{v})$ orcein in $45 \%(\mathrm{v} / \mathrm{v})$ acetic acid and examined for sperm penetration under a phase-contrast microscope at a magnification of $\times 200$ and $\times 400$. Oocytes were designated as penetrated when they had at least one sperm nucleus or male pronucleus with corresponding sperm tail in the vitellus. Those oocytes with more than one sperm nucleus or male pronucleus were considered to be polyspermic.

\section{Assessment of acrosome morphology}

The state of the sperm acrosome was examined by staining with Pisum sativum agglutinin (PSA) labelled with fluorescein isothiocyanate (FITC) as described by Cross et al. (1986) and Liu and Baker (1988) with modification. At the end of prefertilization culture, the sperm suspension of each treatment was smeared on a glass slide, which was precleaned with $100 \%$ ethanol, and dried with mild heat after washing three times by centrifugation $(1200 \mathrm{~g})$ for $3 \mathrm{~min}$ in Dulbecco's phosphatebuffered saline. After fixing and permeabilizing in $95 \%$ ethanol for $1 \mathrm{~h}$ or more, a $25 \mu \mathrm{l}$ drop of $500 \mu \mathrm{g}$ PSA ml ${ }^{-1}$ labelled with 
Table 1. Sperm penetration in vitro of pig oocytes when prefertilization and fertilization media were supplemented with immature porcine follicular fluid (IM-PFF)*, mature porcine follicular fluid (M-PFF) $\dagger$ or fetal calf serum (FCS)

\begin{tabular}{|c|c|c|c|c|c|c|c|}
\hline Supplement & $\begin{array}{c}\text { Concentration } \\
\text { of supplements } \\
(\%)\end{array}$ & $\begin{array}{l}\text { Number of } \\
\text { oocytes } \\
\text { examined }\end{array}$ & $\begin{array}{l}\text { Number of } \\
\text { oocytes } \\
\text { matured } \\
(\%)\end{array}$ & $\begin{array}{l}\text { Number of } \\
\text { oocytes } \\
\text { penetrated } \\
(\%)\end{array}$ & $\begin{array}{l}\text { Number of } \\
\text { monospermic } \\
\text { oocytes } \\
(\%)\end{array}$ & $\begin{array}{l}\text { Mean number of } \\
\text { spermatozoa in } \\
\text { penetrated } \\
\text { oocytes }\end{array}$ & $\begin{array}{l}\text { Number of oocytes } \\
\text { that formed } \\
\text { male pronucleus } \\
(\%)\end{array}$ \\
\hline IM-PFF & $\begin{array}{r}1 \\
10\end{array}$ & $\begin{array}{l}70 \\
72\end{array}$ & $\begin{array}{l}60(86) \\
61(85)\end{array}$ & $\begin{array}{ll}5 & (8)^{\mathrm{a}} \\
4 & (7)^{\mathrm{a}}\end{array}$ & $\begin{array}{lr}4 & (80) \\
4 & (100)\end{array}$ & $\begin{array}{l}1.4^{\mathrm{a}} \\
1.0^{\mathrm{a}}\end{array}$ & $\begin{array}{l}3(60) \\
2(50)\end{array}$ \\
\hline M-PFF & $\begin{array}{r}1 \\
10\end{array}$ & $\begin{array}{l}63 \\
71\end{array}$ & $\begin{array}{l}56(89) \\
61(86)\end{array}$ & $\begin{array}{l}6(11)^{\mathrm{a}} \\
7(11)^{\mathrm{a}}\end{array}$ & $\begin{array}{l}5 \quad(83) \\
7(100)\end{array}$ & $\begin{array}{l}1.3^{\mathrm{a}} \\
1.0^{\mathrm{a}}\end{array}$ & $\begin{array}{l}2(33) \\
3(43)\end{array}$ \\
\hline FCS & $\begin{array}{r}1 \\
10\end{array}$ & $\begin{array}{l}71 \\
73\end{array}$ & $\begin{array}{l}62(87) \\
66(90)\end{array}$ & $\begin{array}{l}56(90)^{b} \\
63(95)^{b}\end{array}$ & $\begin{array}{rr}5 & (9) \\
7 & (11)\end{array}$ & $\begin{array}{l}6.7^{b} \\
6.2^{b}\end{array}$ & $\begin{array}{l}23(41) \\
23(37)\end{array}$ \\
\hline
\end{tabular}

${ }^{*} \mathrm{IM}-\mathrm{PFF}$ was derived from follicles 3-6 mm in diameter. $\nmid \mathrm{M}-\mathrm{PFF}$ was aspirated from matured follicles of cyclic gilts just before ovulation. Values with different superscripts within columns are significantly different $(P<0.05)$.

FITC (Sigma) in distilled water was added on each smear and the slides were kept in a dark and humid chamber at $39^{\circ} \mathrm{C}$ for $1 \mathrm{~h}$, washed and mounted with distilled water. The acrosome of spermatozoa was observed under a fluorescent microscope (Laborlux D, Leitz, Germany) at a magnification of $\times 1000$ and recorded by video cassette recorder. The spermatozoa of which the acrosome region was brightly and uniformly fluoresced were considered to have an intact acrosome.

\section{Experiment 1}

Sperm penetration rate after prefertilization incubation of spermatozoa and insemination in the presence of 1 or $10 \%$ IM-PFF was compared with those in media supplemented with 1 or $10 \%$ M-PFF and 1 or $10 \%$ FCS.

\section{Experiment 2}

Effects of prefertilization incubation and insemination in the presence of different concentrations of IM-PFF $(0,0.01,1$ or $10 \%$ ) with $10 \%$ FCS or $0.4 \%$ BSA on sperm penetration were examined. In some of the oocytes examined in this experiment, the number of spermatozoa tightly bound to the surface of the zona pellucida in each experimental group was also determined using a phase-contrast microscope at a magnification of $\times 200$ and $\times 400$ between mounting and fixing.

\section{Experiment 3}

After prefertilization culture of spermatozoa in the presence of different concentrations of IM-PFF $(0,0.01,0.1,1$ or $10 \%)$ with $0.4 \% \mathrm{BSA}$, the sperm penetration rates in PFF-free fertilization media were recorded. Spermatozoa were washed once by centrifugation at $1200 \mathrm{~g}$ for $3 \mathrm{~min}$ following prefertilization incubation and then added to PFF-free fertilization medium containing oocytes. At the end of the prefertilization culture, a part of the sperm suspension in each experimental group was used to determine the percentage of spermatozoa with an intact acrosome. The number of spermatozoa attaching tightly to the zona was also recorded.

\section{Statistical analysis}

Statistical analyses of data from three replicate trials were carried out by analysis of variance (ANOVA) and Fisher's protected least significant difference test using the STATVIEW (Abacus Concepts, Inc., Berkeley, CA) program. All percentage data were subjected to arc sine transformation before statistical analysis. The mean number of spermatozoa bound to the zona and the rates of acrosome intact spermatozoa were expressed as mean \pm SEM and mean \pm SD, respectively. Probability of $P<0.05$ was considered to be statistically significant.

\section{Results}

Under the same culture conditions as in our previous studies, the maturation rate of pig oocytes was $86 \%$ at $40 \mathrm{~h}$ of culture (Funahashi and Day, 1993a). Ninety per cent of OCC had expanded cumulus cells at the end of culture, but none had expanded corona radiata (Funahashi and Day, 1993b). All semen samples used in the present study had excellent sperm motility.

\section{Experiment 1}

Supplementation of PFF at the level of 1 and $10 \%$ to prefertilization and fertilization media decreased penetration rates to $7-11 \%$ and the mean number of spermatozoa in penetrated eggs (1.0-1.4) as compared with control medium supplemented with FCS (90-95\%, 6.2-6.7, respectively; Table 1). There were no differences between the origin (immature versus mature) of follicular fluid or between concentration (1\% versus $10 \%$ ) of PFF supplementation.

\section{Experiment 2}

In the presence of $10 \% \mathrm{FCS}$, supplementation of $0,0.01,0.1$ and $1 \%$ IM-PFF to prefertilization and fertilization media did 
Table 2. Sperm penetration in vitro of pig oocytes in the presence of follicular fluid at different concentrations in prefertilization and fertilization medium supplemented with fetal calf serum (FCS) or BSA

\begin{tabular}{|c|c|c|c|c|c|c|c|}
\hline $\begin{array}{l}\text { Concentration } \\
\text { of follicular } \\
\text { fluid } \\
(\%)\end{array}$ & Co-supplement $\dagger$ & $\begin{array}{l}\text { Number of } \\
\text { oocytes } \\
\text { examined }\end{array}$ & $\begin{array}{l}\text { Number of } \\
\text { oocytes } \\
\text { matured } \\
(\%)\end{array}$ & $\begin{array}{c}\text { Number of } \\
\text { oocytes } \\
\text { penetrated } \\
(\%)^{c . d}\end{array}$ & $\begin{array}{l}\text { Number of } \\
\text { monospermic } \\
\text { oocytes } \\
(\%)^{\mathrm{de}}\end{array}$ & $\begin{array}{l}\text { Mean number of } \\
\text { spermatozoa in } \\
\text { penetrated } \\
\text { oocytes }^{d}\end{array}$ & $\begin{array}{c}\text { Number of oocytes } \\
\text { that formed } \\
\text { male pronucleus } \\
(\%)^{e}\end{array}$ \\
\hline 0 & $\begin{array}{l}\text { FCS } \\
\text { BSA }\end{array}$ & $\begin{array}{r}100 \\
87\end{array}$ & $\begin{array}{l}85(85) \\
74(85)\end{array}$ & $\begin{array}{l}78(94)^{a} \\
63(85)^{a, b . c}\end{array}$ & $\begin{array}{rr}7 & (9)^{\mathrm{a}} \\
7 & (11)^{\mathrm{a}}\end{array}$ & $\begin{array}{l}6.4^{\mathrm{a}} \\
4.7^{\mathrm{b}, \mathrm{ccd}}\end{array}$ & $\begin{array}{l}21(31) \\
29(46)\end{array}$ \\
\hline 0.01 & $\begin{array}{l}\text { FCS } \\
\text { BSA }\end{array}$ & $\begin{array}{l}74 \\
75\end{array}$ & $\begin{array}{l}68(92) \\
67(89)\end{array}$ & $\begin{array}{l}66(97)^{\mathrm{a}, \mathrm{d}} \\
52(78)^{b, d, e}\end{array}$ & $\begin{array}{rr}5 & (8)^{\mathrm{a}} \\
19 & (37)^{\mathrm{b}}\end{array}$ & $\begin{array}{l}6.3^{\mathrm{a}, \mathrm{d}} \\
2.8^{\mathrm{eff}, \mathrm{g}}\end{array}$ & $\begin{array}{l}25(38) \\
21(40)\end{array}$ \\
\hline 0.1 & $\begin{array}{l}\text { FCS } \\
\text { BSA }\end{array}$ & $\begin{array}{r}108 \\
78\end{array}$ & $\begin{array}{l}98(91) \\
68(87)\end{array}$ & $\begin{array}{l}91(93)^{\mathrm{a}} \\
52(76)^{\mathrm{c}, e}\end{array}$ & $\begin{array}{ll}12 & (13)^{\mathrm{a}} \\
28 & (54)^{\mathrm{b}, \mathrm{c}}\end{array}$ & $\begin{array}{l}4.2^{\mathrm{c}, \mathrm{g}, \mathrm{h}} \\
2.0^{\mathrm{f}, \mathrm{i}}\end{array}$ & $\begin{array}{l}36(41) \\
19(37)\end{array}$ \\
\hline 1 & $\begin{array}{l}\text { FCS } \\
\text { BSA }\end{array}$ & $\begin{array}{l}72 \\
79\end{array}$ & $\begin{array}{l}66(92) \\
69(87)\end{array}$ & $\begin{array}{l}59(89)^{\mathrm{a}, \mathrm{e}} \\
15(22)^{\mathrm{f}, g}\end{array}$ & $\begin{aligned} 9 & (15)^{\mathrm{a}} \\
12 & (80)^{\mathrm{d}}\end{aligned}$ & $\begin{array}{l}3.6^{\text {b.f,h }} \\
1.3^{i}\end{array}$ & $\begin{array}{r}27(47) \\
6(40)\end{array}$ \\
\hline 10 & $\begin{array}{l}\text { FCS } \\
\text { BSA }\end{array}$ & $\begin{array}{l}55 \\
47\end{array}$ & $\begin{array}{l}47(85) \\
40(85)\end{array}$ & $\begin{array}{r}14(30)^{\mathrm{g}} \\
4(10)^{\mathrm{f}}\end{array}$ & $\begin{array}{l}9(64)^{\mathrm{c} d} \\
4(100)^{e}\end{array}$ & $\begin{array}{l}1.6^{\mathrm{e}, \mathrm{i}} \\
1.0^{\mathrm{i}}\end{array}$ & $\begin{array}{l}3(27) \\
1(25)\end{array}$ \\
\hline
\end{tabular}

${ }^{*}$ Follicular fluid derived from immature follicles was used. ${ }^{+} \mathrm{FCS}=10 \%(\mathrm{v} / \mathrm{v})$ fetal calf serum; $\mathrm{BSA}=0.4 \%(\mathrm{w} / \mathrm{v})$ bovine serum albumin. Values with different superscripts within columns are significantly different $(P<0.05)$.

not affect the sperm penetration rate (89-97\%) or monospermic rates $(8-15 \%)$ in oocytes but supplementation with $10 \%$ PFF decreased penetration rate $(30 \%)$ and increased monospermic rate $(64 \%)$ significantly (Table 2 ). Supplementation with $0,0.01$ and $0.1 \%$ PFF together with $0.4 \%$ BSA did not affect the penetration rates $(76-85 \%)$, but the monospermic rates were increased significantly to 37 and $54 \%$ by supplementation of 0.01 and $0.1 \%$ PFF, respectively, to prefertilization and fertilization media (Table 2). Supplementation to a higher concentration of IM-PFF ( 1 and 10\%) increased monospermic rates (80 and $100 \%$, respectively), but decreased penetration rates markedly ( 22 and $10 \%$, respectively). The mean number of spermatozoa in penetrated eggs in the presence of FCS (6.4) and BSA (4.7) decreased as the concentration of IM-PFF increased from 0 to $10 \%$. The mean number of penetrated spermatozoa was lower in the presence of BSA than with FCS at all PFF concentration groups without 10\% PFF supplementation. When oocytes were inseminated in media containing $0.4 \%$ BSA and no IM-PFF, the number of spermatozoa tightly binding on the zona pellucida was smaller $(28.4 \pm 1.8)$ than that $(72.4 \pm 2.7)$ in medium supplemented with $10 \%$ FCS and no IM-PFF (Fig. 1). Furthermore, as the concentration of IM-PFF increased from 0.01 to $10 \%$ in the prefertilization and fertilization media supplemented with FCS or BSA, the number of spermatozoa binding to the zona decreased (Fig. 1).

\section{Experiment 3}

At the end of prefertilization incubation, sperm agglutination was observed, the degree depending on PFF concentration. However, the percentage of spermatozoa with flagellar motility was similar $(80-90 \%)$ among treatments in different concentrations of IM-PFF. All, or rarely some, of the spermatozoa that agglutinated had undergone the acrosome reaction. The percentage of acrosome-reacted spermatozoa was higher at higher concentrations of IM-PFF $(26.9 \pm 4.9 \%$ at $0 \%$ PFF,

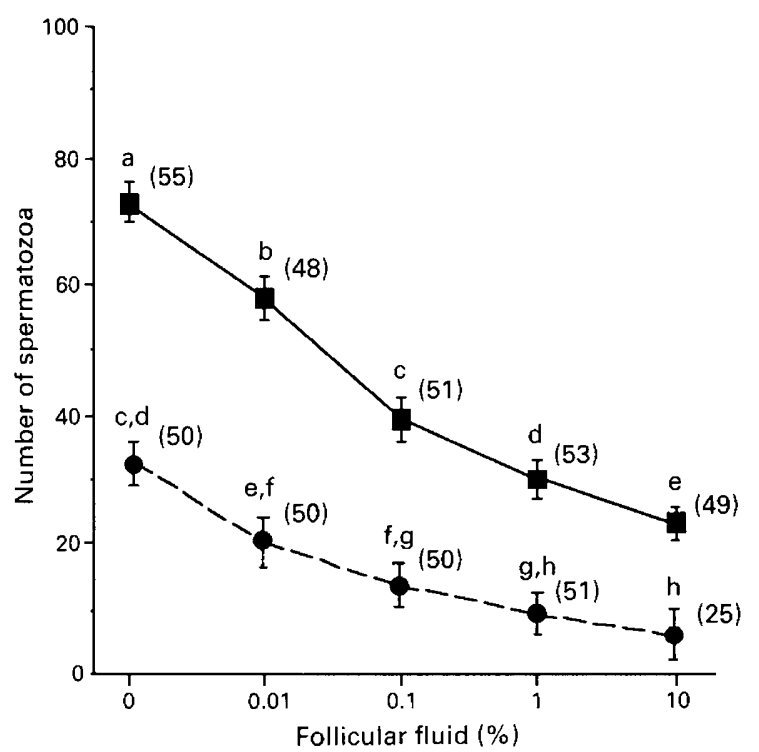

Fig. 1. The effects of porcine follicular fluid from immature follicles (IM-PFF) in prefertilization and fertilization media on the number of spermatozoa that attach firmly to the zona surface of pig oocytes. Spermatozoa were cultured for $90 \mathrm{~min}$ and then cocultured with oocytes for $6 \mathrm{~h}$ in media supplemented with several concentrations of $\operatorname{IM-PFF}(0,0.01,0.1,1$ and $10 \%)$, and ( $10 \%$ FCS or $(0) 0.4 \%$ BSA. Oocytes were examined for the number of spermatozoa binding to the zona pellucida by using a phase contrast microscope after pipetting to remove the spermatozoa not firmly attached. The bars are given as means \pm SEM from three replications. The numbers in parentheses indicate the number of oocytes examined. Different letters denote significant $(P<0.05)$ differences between IM-PFF concentrations.

$56.7 \pm 8.8 \%$ at $0.1 \%$ IM-PFF and $84.3 \pm 15.4$ at $10 \%$ IM-PFF) (Fig. 2.) The addition of PFF during only prefertilization incubation increased the rate of monospermy from $23 \%$ with no 


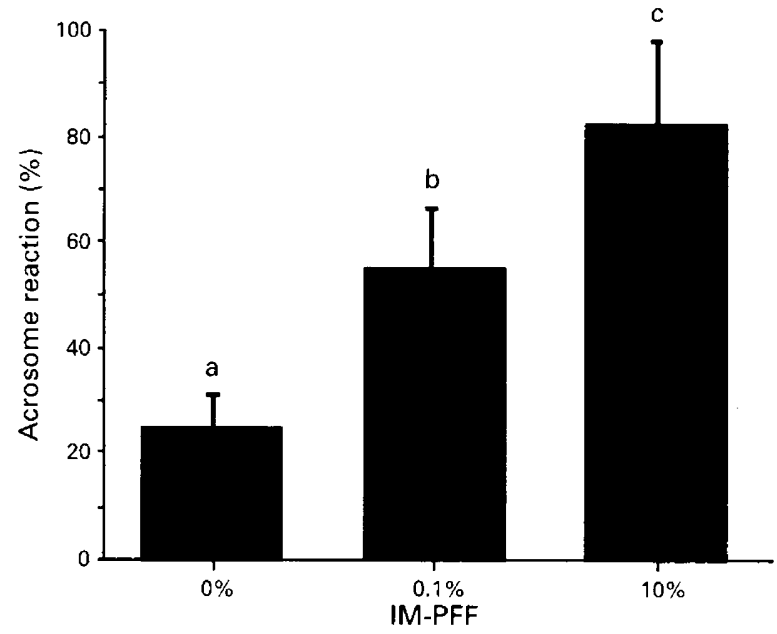

Fig. 2. The effects of porcine follicular fluid from immature follicles (IM-PFF) on the acrosome reaction of spermatozoa at the end of prefertilization incubation. Spermatozoa were incubated in a medium supplemented with $0.4 \% \mathrm{BSA}$ and different concentrations of IM-PFF $(0,0.1$ and $10 \%)$ for $90 \mathrm{~min}$. At the end of prefertilization culture, the acrosome of spermatozoa was stained by using Pisum sativum agglutinin labelled with fluorescein isothiocyanate (FITC), examined under a fluorescence microscope at a magnification of $\times 1000$. The spermatozoa of which the acrosome region was brightly and uniformly fluorescing were considered to have an intact acrosome, and the spermatozoa that did not have an intact acrosome were considered to be acrosome-reacted spermatozoa. The bars are given as means \pm SD from three replications. Different letters denote significant $(P<0.05)$ differences between IM-PFF concentrations.

added PFF to $68 \%$ with $1 \%$ PFF without decreasing penetration rates $(78-80 \%)$, although supplementation with $10 \%$ PFF reduced both polyspermy rate $(13 \%)$ and penetration rate $(37 \%$; Table 3). The mean number of penetrated spermatozoa was reduced from 3.3 to I.I (Table 3) as the IM-PFF concentration during prefertilization incubation was increased from 0 to $10 \%$, respectively. With addition of IM-PFF at $0.1,1$ and $10 \%$ concentration, most (over $90 \%$ ) of the oocytes were penetrated by only one or two spermatozoa. The number of spermatozoa tightly attaching to the zona pellucida at $12 \mathrm{~h}$ after insemination was also decreased at higher concentrations of IM-PFF as was observed in Expt $2(43.1 \pm 2.8$ at $0 \%, 34.0 \pm 3.0$ at $0.01 \%$, $28.0 \pm 2.2$ at $0.1 \%, 24.5 \pm 1.7$ at $1 \%$ and $7.2 \pm 1.3$ at $10 \%$ ).

\section{Discussion}

In the study reported here, the presence of 1 and 10\% PFF in prefertilization and fertilization media affected the rate of sperm penetration of pig oocytes. The present observation in pigs contrasts with the early reports that in hamsters (Barros and Austin, 1967; Gwatkin and Anderson, 1969; Yanagimachi, 1969) and mice (Iwamatusu and Chang, 1969) sperm penetration of oocytes was increased by the presence of hamster or bovine follicular fluid. It is thought that this contrast could derive from the difference in the sperm treatments used to obtain capacitation. Follicular fluid promotes capacitation and acrosome reaction of spermatozoa in vitro in rodents (Barros and Austin, 1967; Gwatkin and Anderson, 1969; Iwamatsu and Chang, 1969; Yanagimachi, 1969) and cattle (Lentz et al., 1982). Our present results on acrosome assessment of spermatozoa at the end point of prefertilization incubation confirm that pig spermatozoa also undergo the acrosome reaction in the presence of PFF. Furthermore, the results indicate that the degree of acrosome reaction depends on the concentration of PFF and demonstrate that the frequency of head-to-head agglutinations of spermatozoa reflect the incidence of acrosome reaction. Although it is known that the head-to-head agglutination of spermatozoa appeared when spermatozoa were preincubated in isolated ligated uterine horns of oestrous gilts (Rath, 1992) or in a medium containing taurine or hypotaurine at concentrations of $0.1-10 \mathrm{mmol}^{-1}$ (Hamano et al., 1989) and when spermatozoa were thawed rapidly following freezing (unpublished observation), the IVF rate was reduced in all cases. Furthermore, since the PFF that was derived from not only mature but also immature follicles modified sperm penetration rates, the PFF effects observed are not confined to substance(s) present only in follicular fluid released at ovulation. Lenz et al. (1982) suggested that glycosaminoglycans present in bovine follicular fluid promote the acrosome reaction of bovine spermatozoa. Recently, Wang et al. (1991) reported that, in the presence of caffeine, supplementation of heparin to the fertilization media reduced the penetration rates of frozen-thawed spermatozoa in pigs.

The number of spermatozoa tightly attached to the zona pellucida at $12 \mathrm{~h}$ after insemination decreased as the PFF concentration during prefertilization incubation increased. It therefore appears that the exposure of spermatozoa to PFF reduced the number of spermatozoa reaching and binding to the zona pellucida. Although only spermatozoa that have undergone acrosome reaction can attach to the zona surface in guineapigs (Huang et al., 1981), acrosome-intact spermatozoa, not the acrosome-reacted ones, bind to the zona in mice (Saling and Storey, 1979). In hamsters, both acrosome-intact and acrosomereacted spermatozoa can bind to the zona (Yanagimachi, 1981; Suarez et al., 1984). Perhaps, in pigs only the acrosome-intact spermatozoa can bind tightly to the zona surface as has been observed in mice. It is known that ZP glycoproteins of pig oocytes are similar to those of mouse oocytes (Wassarman, 1988). The interaction between pig spermatozoa and zona pellucida may therefore be similar to those in mice. It is believed that, at least in some species, there is more than one type of zona receptor on the sperm surface, and the different receptors become active or inactive at different times during sperm-zona interaction (Yanagimachi, 1988). To understand further the reduced binding to the zona surface by acrosome-reacted spermatozoa, it will be important to define more completely the nature of zona receptors on pig spermatozoa at fertilization.

We also found that the presence of $0.1 \%$ PFF in prefertilization and fertilization media and 1\% PFF in only the prefertilization medium did not decrease the penetration rates but did increase monospermic penetration in pig oocytes. This benefit was most evident when PFF was added to only the prefertilization medium ( $68 \%$ monospermy). These results indicate that the block to polyspermy is due to an interaction between PFF and spermatozoa and is not a result of effects on oocytes. In our system, although oocytes were exposed to PFF for $40 \mathrm{~h}$ before insemination, high rates of polyspermy were observed 
Table 3. Effects of porcine follicular fluid in prefertilization culture medium on sperm penetration of pig oocytes

\begin{tabular}{|c|c|c|c|c|c|c|}
\hline $\begin{array}{l}\text { Concentration } \\
\text { of follicular } \\
\text { fluid* } \\
(\%)\end{array}$ & $\begin{array}{l}\text { Number of } \\
\text { oocytes } \\
\text { examined }\end{array}$ & $\begin{array}{l}\text { Number of } \\
\text { oocytes } \\
\text { matured } \\
(\%)\end{array}$ & $\begin{array}{l}\text { Number of } \\
\text { oocytes } \\
\text { penetrated } \\
(\%)\end{array}$ & $\begin{array}{l}\text { Number of } \\
\text { monospermic } \\
\text { oocytes } \\
(\%)\end{array}$ & $\begin{array}{l}\text { Mean number of } \\
\text { spermatozoa in } \\
\text { penetrated } \\
\text { oocytes }\end{array}$ & $\begin{array}{l}\text { Number of oocytes } \\
\text { that formed } \\
\text { male pronucleus } \\
(\%)\end{array}$ \\
\hline 0 & 61 & $55(90)$ & $44(80)^{\mathrm{a}}$ & $10(23)^{\mathrm{a}}$ & $3.3^{\mathrm{a}}$ & $17(39)$ \\
\hline 0.01 & 69 & $63(91)$ & $50(79)^{\mathrm{a}}$ & $21(42)^{a, b}$ & $2.3^{b}$ & $19(38)$ \\
\hline 0.1 & 65 & $59(91)$ & $47(80)^{\mathrm{a}}$ & $30(64)^{b}$ & $1.6^{\mathrm{b}, \mathrm{c}}$ & $20(42)$ \\
\hline 1 & 77 & $72(94)$ & $56(78)^{\mathrm{a}}$ & $38(68)^{b}$ & $1.5^{\mathrm{b}, \mathrm{c}}$ & $28(50)$ \\
\hline 10 & 91 & $84(92)$ & $31(37)^{b}$ & $27(87)^{c}$ & $1.1^{c}$ & $16(51)$ \\
\hline
\end{tabular}

*Spermatozoa were cultured in media supplemented with follicular fluid derived from immature follicles for 90 min. Values with different superscripts within columns are significantly different $(P<0.05)$.

when the PFF was not included in prefertilization medium or prefertilization and fertilization media.

We also found that prefertilization incubation of spermatozoa in the presence of PFF induced the acrosome reaction of spermatozoa and decreased attachment of spermatozoa to the zona pellucida with a subsequent increase in monospermic penetration. These results suggest that a low concentration of PFF in prefertilization media increases the rates of monospermic entry by induction of the acrosome reaction and a consequent reduction in the number of spermatozoa that bind to the zona pellucida. Polyspermic penetration of normal pig oocytes in vivo has been observed by means of surgical insemination into the oviduct or relaxation of uterotubal junction by progesterone injection (Day and Polge, 1968; Hunter, 1972; also see reviews by Hunter, 1990, 1991). Polyspermy of pig eggs in vivo may therefore be primarily due to increased penetration before the block to polyspermy has become fully established, because an abnormally large number of spermatozoa reach the egg surface (Hunter, 1990). Hansen et al. (1991) reported that $0.51 \pm 0.10 \%$ of the available follicular fluid was present in the pig oviduct near the time of ovulation and that this amount had decreased 10-12-fold $4 \mathrm{~h}$ later. Since these in vivo concentrations of PFF are consistent with the concentrations of PFF that increased monospermic penetration in vitro without decreasing penetration rates, it seems possible that the PFF in the oviduct may assist in the prevention of polyspermy in vivo.

Nagai and Moor (1990) reported that coculture of spermoviduct cells for suitable duration followed by IVF on oviductal cells selectively reduced the rates of polyspermy to $40-50 \%$. Coculture of spermatozoa with oviductal cells maintained both flagellar movement and free-swimming motility of spermatozoa. Although the flagellar motility was increased by exposure of PFF (authors unpublished observation), our results of headto-head aggregation of spermatozoa by PFF treatment was in contrast to the observations of Nagai and Moor (1990). Although the preincubation of spermatozoa in the oviduct and uterus of the oestrous female following insemination induces capacitation and also acrosome reaction, there may be some differences in the mechanism of action between the beneficial effects of PFF and those of oviductal secretions.

In the present study, supplementation of $10 \% \mathrm{FCS}$ to prefertilization and fertilization media not only increased the number of spermatozoa that penetrated or attached per oocyte but also reduced the effects of PFF on sperm penetration and sperm binding to the zona compared with supplementation with BSA. Cran and Cheng (1986) reported that the binding properties of FCS reduce the available level of calcium that is necessary for exocytosis and cortical reaction. Since the presence of extracellular calcium is also essential for acrosome reaction and hyperactivation of spermatozoa (Fraser, 1984), it appears that supplementation of FCS to prefertilization and fertilization media is not recommended.

In conclusion, we suggest that the prefertilization incubation of porcine spermatozoa in porcine follicular fluid reduces both the number of spermatozoa that bind to the pig zona pellucida and the incidence of polyspermy.

The authors thank K. Niwa for valuable advice, S. A. Ericsson for assistance with the acrosome assessment techniques, T. Koerkenmeier for technical assistance, T. C. Cantley, A. Rieke and S. Peters for transport of samples, Monfort Pork Inc., St Joseph, MO, for their donation of ovaries and $\mathrm{B}$. Nichols for secretarial assistance with the preparation of this manuscript. H. Funahashi is the recipient of a University of Missouri Miller Fund and Food for the $21^{\text {st }}$ century postdoctoral fellowship. This manuscript is a contribution from the Missouri Agricultural Experiment Station: Journal Series Number 11,770 .

\section{References}

Barros C and Austin CR (1967) In vitro acrosomal reaction of golden hamster spermatozoa Anatomy Review 157348 (Abstract)

Beckmann LS and Day BN (1991) Culture of the one- and two-cell porcine embryo: effects of varied osmolarity in Whitten's and Kreb's ringer bicarbonate media Theriogenology 35184 (Abstract)

Beckmann LS, Cantley TC, Reike AR and Day BN (1990) Development and viability of one- and two-cell porcine embryos cultured through the 'four-cell block' Theriogenology 331983 (Abstract)

Cheng WTK, Polge C and Moor RM (1986) In vitro fertilization of pig and sheep oocytes Theriogenology 25146 (Abstract)

Cran DG and Cheng WTK (1986) The cortical reaction in pig oocytes during in vivo and in vitro fertilization Gamete Research 13 241-251

Cross NL, Morales P, Overstreet JW and Hanson TW (1986) Two simple methods for detecting acrosome-reacted human sperm Gamete Research 15 213-226

Day BN and Polge C (1968) Effects of progesterone on fertilization and egg transport in the pig Joumal of Reproduction and Fertility 17 227-230

Fraser LR (1984) Mechanisms controlling mammalian fertilization Oxford Reviews of Reproductive Biology 6 174-225 
Funahashi H and Day BN (1993a) Effects of different serum supplements in maturation medium on meiotic and cytoplasmic maturation of pig oocytes Theriogenology $39965-973$

Funahashi H and Day BN (1993b) Effects of duration of exposure to supplemental hormones on cytoplasmic maturation of pig oocytes in vitro Journal of Reproduction and Fertility 98 179-185

Gwatkin RBL and Anderson OF (1969) Capacitation of hamster spermatozoa by bovine follicular fluid Nature 224 1111-1112

Hagen DR, Prather RS, Sims MM and First NL (1991) Development of one-cell porcine embryos to the blastocyst stage in simple media Joumal of Animal Science 69 1147-1150

Hamano S, Naito K, Fukuda Y and Toyoda Y (1989) In vivo capacitation of boar ejaculated spermatozoa: effect of conditioned media prepared from preincubated sperm suspension Gamete Research 24 483-489

Hansen C, Srikandakumar A and Downey BR (1991) Presence of follicular fluid in the porcine oviduct and its contribution to the acrosome reaction Molecular Reproduction and Development 30 148-153

Huang TTF, Flemming AD and Yanagimachi R (1981) Only acrosome-reacted spermatozoa can bind and penetrate into zona pellucida: a study using guinea pig Joumal of Experimental Zoology 217 286-290

Hunter RHF (1972) Local action of progesterone loading to polyspermic fertilization in pigs Joumal of Reproduction and Fertility 31 433-444

Hunter RHF (1990) Fertilization of pig eggs in vivo and in vitro Joumal of Reproduction and Fertility Supplement 40 211-226

Hunter RHF (1991) Oviduct function in pigs, with particular reference to the pathological condition of polyspermy Molecular Reproduction and Development 29, 385-391

Hunter RHF and Hall JP (1974) Capacitation of boar spermatozoa: synergism between uterine and tubal environments Journal of Experimental Zoology 188 203-214

Iritani A, Niwa K and Imai H (1978) Sperm penetration in vitro of pig follicular oocytes matured in culture Joumal of Reproduction and Fertility 54 379-383

Iwamatsu T and Chang MC (1969) In vitro fertilization of mouse eggs in the presence of bovine follicular fluid Nature 224 919-920

Lenz RW, Ax RL, Grimek HJ and First NL (1982) Proteoglycan from bovine follicular fluid enhances an acrosome reaction in bovine spermatozoa Biochemical and Biophysical Research Communications 106 1092-1098

Liu DY and Baker HWG (1988) The proportion of human sperm with poor morphology but normal intact acrosomes detected with Pisum sativum agglutinin correlates with fertilization in vitro Fertility and Sterility 50 288-293

Mattioli M, Galeati G and Seren E (1988) Effect of follicle somatic cells during pig oocyte maturation on egg penetrability and male pronucleus formation Gamete Research 20 177-183

Misener M, Pollard JW and Metzger K (1991) In vivo culture of porcine embryos in CZB medium Theriogenology 35244 (Abstract)

Nagai T and Moor RM (1990) Effect of oviduct cells on the incidence of polyspermy in pig eggs fertilized in vitro Molecular Reproduction and Development $26377-382$

Nagai T, Niwa K and Iritani A (1984) Effect of sperm concentration during preincubation in a defined medium on fertilization in vitro of pig follicular oocytes Journal of Reproduction and Fertility $70271-275$
Nagai T, Takahashi T, Masuda H, Shioya Y, Kuwayama M, Fukushima M, Iwasaki S and Hanada A (1988) In-vitro fertilization on pig oocytes by frozen boar spermatozoa Journal of Reproduction and Fertility 84 585-591

Nagai T, Takahashi T, Shioya Y and Oguri N (1990) Maturation and fertilization of pig follicular oocytes cultured in pig amniotic fluid Theriogenology 34 195-204

Naito K, Fukuda Y and Toyoda Y (1988) Effects of porcine follicular fluid on male pronucleus formation in porcine oocytes matured in vitro Gamete Research 21 289-295

Petters RM and Reed ML (1991) Addition of taurine or hypotaurine to culture medium improves development of one- and two-cell pig embryos in vitro Theriogenology 35253 (Abstract)

Petters RM, Johnson BH, Reed ML and Archibong AE (1990) Glucose glutamine in inorganic phosphate in early development of the pig embryo in vitro Joumal of Reproduction and Fertility $89269-275$

Rath D (1992) Experiments to improve in vitro fertilization techniques for in vivo-matured porcine oocytes Theriogenology 37 885-896

Reed ML, Illera MJ and Petters RM (1992) In vitro culture of pig embryos Theriogenology 37 95-109

Saling PM and Storey BT (1979) Mouse gamete interaction during fertilization in vitro: chlorfelracycline as a fluorescent probe for the mouse sperm acrosome reaction Journal of Cell Biology 83 544-555

Suarez SS, Katz DF and Meizel S (1984) Changes in motility that accompany the acrosome reaction in hyperactivated hamster spermatozoa Gamete Research $10253-265$

Wang WH, Niwa K and Okuda K (199I) In-vitro penetration of pig oocytes matured in culture by frozen-thawed ejaculated spermatozoa Journal of Reproduction and Fertility 93 491-496

Wassarman PM (1988) Zona pellucida glycoproteins Annual Review of Biochemistry 57 415-442

Whitten WK and Biggers JD (1968) Complete development in vitro of the preimplantation stage of the mouse in a simple chemically defined medium Journal of Reproduction and Fertility 17 399-401

Yanagimachi R (1969) In vitro capacitation of hamster spermatozoa by follicular fluid Journal of Reproduction and Fertility 18 275-286

Yanagimachi R (1981) Mechanisms of fertilization in mammals. In Fertilization and Embryonic Development In Vitro, pp 81-182 Eds L Mastroanni Jr and JD Biggers. Plenum Press, New York

Yanagimachi R (1988) Mammalian Fertilization. In The Physiology of Reproduction, pp 135-185 Eds E Knobil, JD Neill, LL Ewing, GS Greenwald, CL Martert and DW Pfaff. Raven Press, New York

Yoshida M (1987) In vitro fertilization of pig oocytes matured in vivo japanese Joumal of Veterinary Science 49 711-718

Yoshida M, Ishizaki Y and Kawagishi H (1990) Blastocyst formation by pig embryos resulting from in-vitro fertilization of oocytes matured in vitro Journal of Reproduction and Fertility 88 1-8

Yoshida M, Ishigaki K and Pursel VG (1992) Effect of maturation media on male pronucleus formation in pig oocytes matured in vitro Molecular Reproduction and Development 31 68-71

Zheng YS and Sirard MA (1992) The effect of sera, bovine serum albumin and follicular cells on in vitro maturation and fertilization of porcine oocytes Theriogenology $37779-790$ 